\title{
Discourse and/as Social Practice - the Analysis of the Problem of Resistance and
} Hegemony

Anita Dremel

Renato Matić

University of Zagreb

adremel@hrstud.hr

rmatic@hrstud.hr

\section{DOI:10.5901/mjss.2014.v5n22p155}

\begin{abstract}
The aim of this paper is to discuss how approaches to discourse can face the charges for discursive idealism, and to show it empirically through the analysis of gender discourse in the mapping and reception of the life and work of Marija Jurić Zagorka, the first Croatian woman journalist, proto-feminist and the writer of popular fiction. The method is critical discourse analysis, which follows Foucault's concept of discourse, but attempts to overcome the criticism Foucault received for overemphasizing the potential of discourse to manipulate people. This is the reason motivating many revisions of Foucault's method mainly by attempting to introduce a theory of action in order to make a socially active subject link discourse and reality. CDA authored by Norman Fairclough introduces a three-dimensional concept of discourse (as text, discursive practice and social practice) and uses the Gramscian concept of hegemony (rather than ideology) to strategically try and surpass the charge for discourse determinism. Seeing discourse as social practice enables us to combine the perspectives of structure and action, because practice is at the same time determined by its position in the structured network of practices and a lived performance, a domain of social action and interaction that both reproduces structures and has the potential to transform them. Gramsci's concept of hegemony sees cultural production as a tool that maintains domination by securing the spontaneous consent of the subordinated. The results suggest a possible (subversive) intervention into the sphere of discursive practices (hegemonic struggle of different voices for supremacy in the order of discourse defining the reception of Zagorka) and indicate that detailed empirical research on discursive effects in a series of domains is a method of research on political investment of the order of discourse into social change.
\end{abstract}

Keywords: discourse, gender, popular culture, hegemony, social practice

\section{Introduction}

The research attention paid to discourse in humanities and social sciences in the last several decades presents a ramification of the so called linguistic turn, which has directed the mainstream research interests towards the questions of meaning-production, subjectivity, social construction of identity etc. Although discourse was originally studied predominantly within the framework of linguistics, the influence of deconstruction, poststructuralism and the performative turn have widened the meaning of the term discourse. Consequently, there are today quite a few definitions of and approaches to discourse analysis, such as that of Fairclough (1995), Wodak (2001), van Dijk (1990) etc. Sociologically relevant conceptualizations of discourse are particularly the ones influenced by Foucault's method, because, among other reasons, Foucault sees social power as discursive. There is almost an overload of interpretations and (mis) uses of Foucault' approach, although there is no one Foucault's method. Our task is therefore to firstly give an overview of the history and (disciplinary) versions of discourse analyses and then to move towards outlining Foucault's notion of discourse. We will discuss some criticism Foucault received, particularly the charges for discursive idealism, and try to show how a critical discourse approach, specifically the one authored by Norman Fairclough, works to overcome the criticism Foucault received for overemphasizing the potential of discourse to manipulate people, and offer a view of the potentially subversive social action. There are two main foci Fairclough complements the method with to achieve this objective: he conceptualizes discourse as consisting of the three dimensions (text, discursive practice and social practice), and he introduces the concept of hegemony over that of ideology to provide for the struggle between tactically polyvalent voices for supremacy in the order of discourse. 
Having leaned the methodological framework of critical discourse analysis against a background, the paper proceeds to empirically apply the method through the analysis of gender discourse in the mapping and reception of the life and work of Marija Jurić Zagorka (born 1873, died 1957), the first Croatian woman journalist, proto-feminist and the writer of popular fiction. Zagorka was on the one hand adored by her readers, immensely popular, and due to that in the position to mobilise action towards feminist goals. On the other, however, she was severely criticized and even treated with utter disgust by the established critics. This duality is also evident in her invisibility in the overviews of the history of Croatian literature and journalism, critical treatises, encyclopaedias, or scientific debates; and on the contrary her immense visibility and presence in the popular cultural imaginary. Our analysis in this paper specifically focusses on the gender discourse that spans past the borders of science and literature and can be, as the results suggest, considered as their confluence. Informing the critical analysis of gender discourse with the analysis of context and paying heavy attention to the critique of ideology, the paper reveals power-imbued strategies of the certain historical mapping and reception of Zagorka's life and work. Increased academic interest in popular culture enabled this new visibility of previously absent objects from the scientific study, although new investments into the power regime must not be disregarded. We will in this paper, accordingly, analyse the status and (in)visibility of Zagorka as an instantiation of popular culture in the Croatian context. As this is also a contribution to feminist epistemology and the critiques of androcentric theories of modernization, special awareness of reflexivity regarding positionality will be pursued throughout.

\section{Methodological framework - on analysing language, culture, and society}

\subsection{On discourse and discourse analyses}

The last several decades have been marked by the appearance and development of various interdisciplinary fields, including systems theory, cognitive science, and discourse analysis, which presents a refreshing contrast compared to selfisolating tendencies of scientific disciplines on the one hand (cf. Beaugrande, 1996) and the ambitions to create a unified science on the other (Beaugrande, 2006: 29). Discourse analysis as a qualitative methodological approach in social sciences and humanities presents an umbrella term (Cameron, 2001: 1) and includes various research approaches, like ethnography of speaking, conversation analysis, interactional sociolinguistics and critical discourse analysis (Wetherell, 2001).

Discourse analysis is the ramification of the so called linguistic turn in social sciences and humanities, and although there is a multitude of approaches, they all share the attitude that what makes the social world, including our identities, can partly be found in discourse. What is it then that we analyse in discourse analysis? Discourse is primarily a term from linguistics, where it denotes language beyond sentence-level and includes a series of texts. Litosseliti \& Sunderland (2002) add the interpersonal focus to this definition, stressing that discourse is not only a supra-sentential element, but that it is functional in terms of language use, which means that it communicates meanings in a certain context. Also, discourse is used to refer to the language particular to certain social situations (e.g. classroom discourse). Various authors have defined it in different ways: as the real practice of speaking and writing (Woodilla, 1998), or, more specifically, as an interconnected set of texts and the practices of their production, distribution, and reception (Phillips \& Hardy, 2002: 3). Social reality is constructed and made real through discourses, and social interactions cannot be understood without reference to discourses that give them meaning (Phillips \& Hardy, 2002: 3).

Text should be distinguished from discourse, which is text in context (van Dijk, 1990: 164), although it cannot be separated from discursive and social practice (Fairclough, 1992). Texts can be considered discursive units and material manifestations of discourse (Chalaby, 1996). The notion of text includes many different forms, from written texts to pictures, symbols, artefacts etc. (Grant, Keenoy, and Oswick, 1998). Texts are places in which the complexes of social meanings are produced in a certain historical situation of their production, which in a partial way notes the history of participants in the production of texts and the institutions involved - thus, a partial history of language and social system. Discourse analysis is thus aimed at establishing the constructionist effects of discourse through the structured and systematic analysis of texts. However, discourse does not possess meanings immanently, it is shared and social, and emanates from interaction between groups and institutions. Accordingly, if we aim to understand discourses, we must understand the contexts in which they appear (van Dijk, 1997).

The Dictionary of sociology (Abercrombie et al., 2008: 50) defines discourse as the corpus of language use unified by some common assumptions, which implies that discourse allows us to think, speak and do one thing, and exclude the thinking, speaking and doing of the other, directing the attention of sociology to the social effects of that exclusion. This interest in studying the processes of social construction of the invisible reality, reality that is taken for granted, with focus on the 
connection between the power regime and knowledge is strongly influenced by the work of Michel Foucault. Our task is therefore to look more closely into this intellectual heritage.

\subsection{Foucault's heritage and influence}

Foucault's decision to focus on discursive practices is an attempt to avoid structuralism and hermeneutics (Dreyfus \& Rabinow, 1982: xiii-xxiii). Foucault dealt with discourses of human sciences (medicine, psychiatry, economics, grammar), but his method is in principle generalizable to all discourses (Fairclough, 1992: 38). He does not put accent on the analysis of texts, but on the conditions of possibility of discourse and the rules of formation that define the possible objects of knowledge, subjects, concepts etc. (Robin 1973: 83, as found in Fairclough, 1992: 38).

Foucault differentiates between discourse and language. He is less interested in the formal possibilities offered by the language system, and more in the fact that certain words have been uttered. Discourse is thus for Foucault not only the form of knowledge about the way of thinking and acting in a given culture, but also an event. Also, discourse is historical, but with a lasting relevance, as archive, which denotes the accumulated existence of discourses (Foucault, 1989: 25). Discourses exist in a net-like relationship with other discourses, and that relationship is hierarchical (the order of discourse).

The idea of discourse developed by Foucault has been accepted by a number of analysts interested in the relationship between society and language. Foucault's method is according to Kendall and Wickham (1999) an important contribution to qualitative research in social sciences for several reasons: it deeply problematizes simplified categories, it has no assumption of progress, speaks of the history of the present, disturbs the assumed and the taken for granted, looks for contingencies instead of causes and exposes oppositions.

Although qualitative social science research seems much indebted to Foucault, there is no one or strictly defined Foucauldian method of discourse analysis. There are various models developed on the basis of Foucault's contribution (cf. Bannister, 1995; Fairclough, 1995; Parker, 1992; Potter \& Wetherall, 1987), and many of them differ according to how they position themselves regarding the criticism addressed to Foucault on several accounts. Two most widespread critiques revolve around the potentially present discursive idealism and the problematic status of the possibility of subversive action, or in other words, the relationship between power and resistance.

The criticism stresses that although Foucault discusses (1982) various forms of fight and resistance, he leaves us with the dominant impression that people are entirely subject to the systems of power, which are impossible or almost impossible to subvert and resist. Also, Foucault does not speak so much of the real practice of writing and speaking, but of the discursive practice as a system of anonymous historical rules (1989), which is a move that reduces the notion of practice to its customary opposite, structure.

Some scholars of Foucault (Hooks, 2001) have, however, warned that Foucault emphasizes the political utility and critical capacity of analysing discourse as a powerful means of enabling forms of critique and resistance, even when his method is read in a 'descriptivist' manner and turned into a kind of diagnosis of culture and society, enabling only a characterization of a variety of historical phenomena (like for example in case of McHoul and Grace, 1997). The often confusing and criticism-inspiring moments in Foucault's writing revolve around his conceptualization of the relationship between discursive and non-discursive, knowledge and power, especially when Foucault stresses the effects of discursive practices that make it virtually impossible to think outside of them (Hook, 2001). To be outside of discourse is to be mad, by definition, to be beyond comprehension and reason (Young, 1981). Discourse is so tightly associated with the regime of power, it ensures the reproduction of the social system through forms of selection, exclusion and domination (Young, 1981). Foucault's theorization of truth and authorship as the functions of discourse particularly fuelled the criticism in this direction, because by demonstrating how certain understanding re-circulate, Foucault seems to suggest that we "have dangerously overestimated the creative and resourceful abilities of discourse" (Hooks, 2001: 11).

We agree that Foucault's position should be read as going against a deterministic discursive idealism in the sense that not everything can be analysed as a text or a language only, and towards the re-acclamation of the material forms of power. However, we feel that to analytically show the social practice quality of discourse, we need to include direct analyses of real examples of that practice, including texts, without which it is hard to imagine the possibility to extrapolate from structure to practice. This effort is, close to Foucault's concept of discourse, undertaken by Norman Fairclough, who has developed a model of critical discourse analysis that takes text and context into account in analysing discourse, and that has been reviewed as usable in social sciences. Fairclough's two important strategies in that effort are his three-dimensional concept 
of discourse and the inclusion of the theory of hegemony, along Gramsci's (1971) lines. We therefore proceed to give an outline of his method.

\subsection{Critical discourse analysis}

Critical discourse analysis (CDA), heavily informed by the work of Michel Foucualt, is the method of research into the place of language-in-use in the construction and regulation of the social world. It presents an attempt to overcome the accusations for discursive idealism and the passivation of social actors by analysing discursive building blocks of the processes of social construction of reality. CDA offers the theory of the connection between social practice and discourse structures, as well as a wide range of tools and strategies for analysing concrete contextualized uses of language/performances of meanings. The critical approach to analysing discourse should be positioned between theory, methodology and politics (Meyer, 2001: 15), with the procedure that reduces rather than extends the textual in its analysis (Meyer, 2001: 16).

The "critical" dimension of this method refers to the practical linking of the social and political engagement with the sociologically informed construction of society, with the recognition that the interconnectedness of things and the causeand-effect chain are deformed inter alia discursively; and that the task of critique is to make this interconnectedness visible (Wodak, 2001: 2). Fairclough (1995: 50) defines the critical task as commitment to the dialectical method. Consequently, CDA demands of us to distance ourselves form the data, to embed them into the social, to explicitly take a political stand and to be self-reflexive in the course of research (Wodak, 2001: 9).

CDA is for Fairclough both theory and method, in a transdisciplinary dialogue with other theories and methods (2001: 121). Relevantly, it is a view of semiosis as an element or 'moment' of material social processes, which enables a new way of analysing semiosis within wider analyses of social processes (Fairclough, 2001: 121). The motivation to focus on the social practice perspective lies in the possibility to combine the perspectives of structure and agency, because practice is at the same time determined by its position in the structured network of practices and a lived performance, a domain of social action and interaction that both reproduces structures and has the potential to transform them (Fairclough, 2001: 122).

According to Meyer (2001: 22), Fairclough takes a specific position of the middle-range theory and focusses on the social conflict in the neo-Marxist tradition, with special emphasis on the elements of domination and resistance as manifested in discourse. Economic activity, social relationships, identities, values, consciousness and semiosis are dialectically connected elements of practice, never completely separable. Social practices connected in a certain way constitute a social order, and the order of discourse is its semiotic aspect (Fairclough, 2001: 124). The order of discourse is thus the social structuring of a semiotic difference - a certain social ordering of relationships between different ways of giving meaning, or different discourses and genres.

As indicated earlier, Fairclough (1992) develops a three-dimensional framework for analysing discourse. The first dimension is discourse as text - it refers to linguistic features like the choice of vocabulary (expression, metaphors), grammar (transitivity, modality), cohesion (conjunctions) and text structure. The second dimension is discourse as discursive practice - it refers to the production, circulation and consumption of texts. This means that in analysing the grammar, vocabulary or structure of texts, the attention is paid to speech acts, coherence and intertextuality - the aspects of text that connect it with context (Blommaert \& Bulcaen, 2000: 449). The third dimension is discourse as social practice, which implies ideological effects and hegemonic processes in which discourse participates.

These three dimensions help Fairclough operationalize the Foucault-informed statement about the socially constitutive properties of discourse. Such conceptualizing of discourse accentuates the mutual determination and connection of the part and the whole, the micro and macro levels, which helps frame this model within the theory of ideological processes, because discourse is seen in terms of hegemonic processes and changes in hegemony.

The notion of hegemony is very important here as a certain social structuring of semiotic difference may become hegemonic i.e. a part of the legitimizing common sense that supports the relationships of domination. However, contrary to the dominant ideology thesis, hegemony can be to a greater or lesser extent challenged, implying that the order of discourse is not a closed and rigid system but subject to risks springing from real interaction (Fairclough, 2001: 124).

When considering the relationship between language, power, and ideology, Fairclough speaks of ideological-discursive formations (IDFs), which is a direct influence of Althusser (1971). IDF is an ideological position that strives to affiliate with different forces in institutions. The way a subject speaks is normatively connected with the position they occupy, because it is from this position that they acquire a way of seeing underlying a certain way of talking, always shaped by ideological norms. Ideology can, thus, be understood as the representation of the imaginary relationship of individuals towards the 
conditions of their existence. It interpellates individuals as subjects or, in other words, places them in a position within the ideological frame. Patriarchal ideology, for instance, interpellates individuals as more powerful men and less powerful women, and some claim that popular culture interpellates readers as consumers (cf. Strinati, 2004: 142). However, we wish to distance ourselves here from the dominant ideology thesis and the determinism of class, and so introduce Gramsi's concept of hegemony into the perspective, because the notion of hegemony tries to overcome the assumption of the ultimate primacy of the production mode. Also, Gramsi (1971) makes a difference between coercive and consensual control, defining hegemony as a cultural and ideological means of perpetuating domination by securing the spontaneous consent of the subordinated.

Here is where the potential to theorize subversion appears. Namely, the naturalized discursive conventions are the most efficient way of reproducing cultural and ideological dimensions of hegemony (Fairclough, 1995: 94), which makes the effort to denaturalize existing conventions an important goal of challenging the hegemonic struggle. In other words, the hegemony of one group over the other partly consists of the possibility to intervene into and form discursive practices. This intervention is also called the technologization of discourse, and Fairclough (1995: 102-104) describes it as the process of possible intervention into the sphere of discursive practices with the aim to construe a new hegemony in the order of discourses of a certain institution. Also, Foucault (1981) sees the technologization of discourse as a powerful connection between social sciences and the structures of power in constituting modern biopower. Discourse can in this context be seen as one of the forces in what Rose and Miller (1990) call the "technologies of governance", which include strategies, techniques and procedures that different forces use to try and make their programs feasible.

Technologization of discourse brings changes to the hegemonic struggle. It is for our analysis important to stress once again that people can react to it in different ways: accept the demands for change, tactically act they accept them, reject them etc. Such view of the hegemonic struggle of discourses for supremacy is extremely relevant in this approach, as it provides for a less violent reading of the role and place of Marija Jurić Zagorka and her popular fiction in the Croatian cultural history. In the following chapter we analyse the discourse surrounding the interpretation of her work and producing the dynamics of her visibility/presence/adoration and invisibility/absence/detestation. We retain the awareness about qualitative shifts in the social functioning of discourse in different historical moments or in the cultural dominant of an epoch (Williams, 1981), as well as of the multifunctionality of discourse and inherent polysemy of language. Zagorka was a producer of texts for massive audience at times of big social, economic and political changes - when discourse technologization is particularly visible - and she had to work with different constructions of social identities. All texts express the social identity of their producers and address the supposed identities of their readers, and texts for massive audience, especially when they have explicit politics and purpose in mind (as Zagorka's do) actively construct imagined identities for their consumers, creating for them positions they may or may not occupy (Fairclough, 1995: 123), . Thus, detailed empirical research of discursive effects in a series of domains is a method of research into progressive political and ideological investment of the order of discourse into social change (Fairclough, 1995: 123), along the lines of what Spivak (1988) calls strategic essentialism.

\section{The case of Marija Jurić Zagorka - critical discourse analysis of her life, work and reception}

\subsection{The problematic status of popular culture or on the politics of exclusion}

Here we will attempt to show on a concrete contextualized example that detailed empirical research of specific discursive effects is a means of research on the investment of the order of discourse into social change (Fairclough, 1995: 123). On the analysis of the critical reception of popular culture, we will show that the effects Zagorka's popular cultural production exerted cannot be adequately grasped without taking the mentioned complementary perspectives of discourse as live social practice and hegemony as the struggle of voices for supremacy (always in negotiation with the dominant discourse) into account.

Popular culture is here revealed as the exemplary place of hegemonic negotiation of different discourses. There are different approaches to define popular cultural practices and their social functions. Popular culture was frequently associated with the rise of national consciousness from the late 18th century on (e.g. Burke, 1978), but its meaning is not that strictly defined. Williams (1976) states that popular can mean from the point of view of the people, but also from the point of view of those who want to govern the people, usefully noticing that it is not the people who talk about popular culture. He also mentions the definition of popular culture as inferior, the culture produced so as to appeal to the recipient, to mass audiences. Generally, there has been a strong trend of viewing popular cultural production in pejorative terms (in neo-Marxist theories of cultural industry, theories of mass society, the Frankfurt School, and even some feminist theories), 
especially the one primarily written for women and with extra-literary political objectives in mind. Various negative effects of producing and consuming popular culture have been emphasized (Lewis, 1978: 9): the negative character of the production of popular culture, negative effects on highbrow culture, the consumers of popular culture, and the entire society (see table 1).

Table 1. Overview of pejorative critiques of popular culture

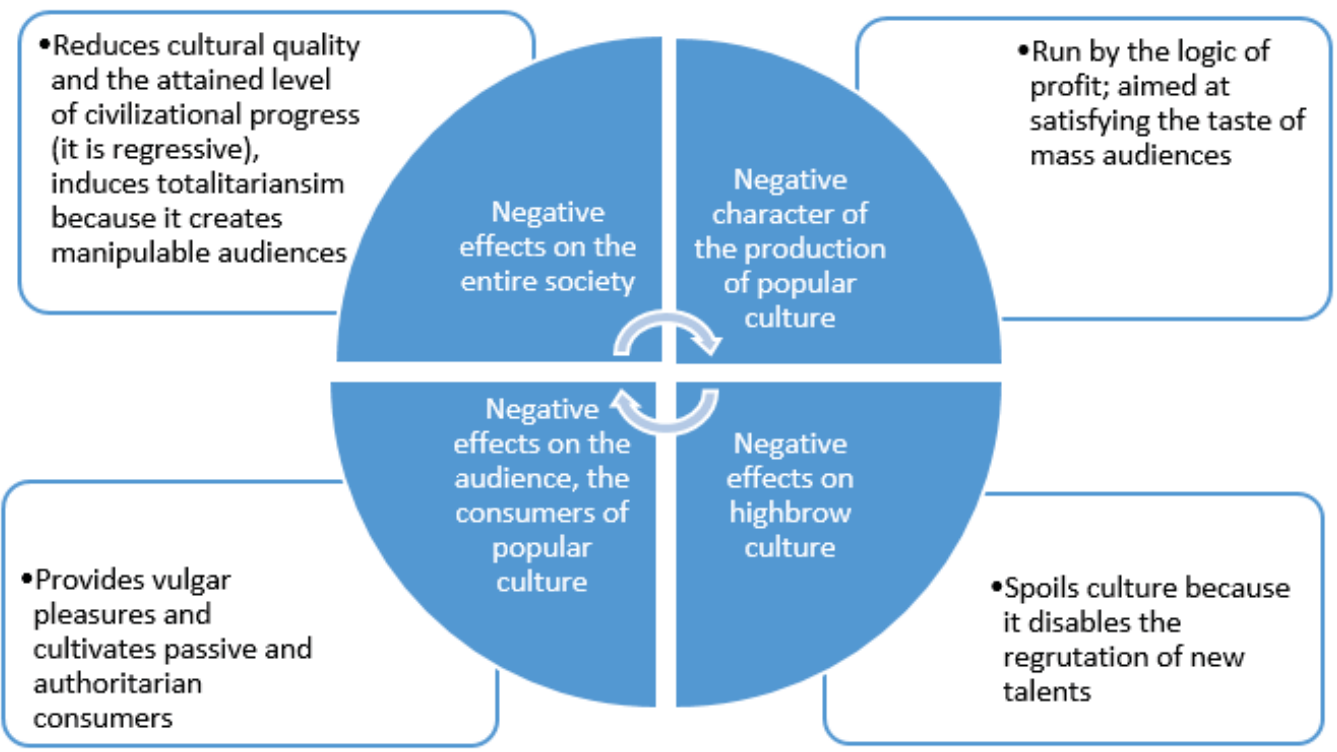

At first view, Zagorka may seem to yield to such criticism. On the level of narrative structure, Zagorka's novels are schematic, simplified, and episodic (which is also conditioned by the modes of production and distribution of texts), and on the level of narrative strategies they stimulate empathy, identification, and intensive physical sensation caused by the experience of reading (the novels are interesting, full of intrigues, cliff-hangers, and suspense; characters are mostly flat, and a happy ending is a generic must). Also, Zagorka produced texts in lucrative quantities, for massive audiences and with political objectives in mind. Zagorka depended on and adjusted to the audience and the market, but at the same time never gave up her political aims. Her heroines use discursive strategies in order to appropriate the male perspective and so make a change regarding the rights of women. The end of the story establishes what we would call a strong patriarchal discursive formation, because the heroines find happiness in marital union. This has been the main reason for even some feminists (Modleski, 2008; Snitow, 1996) to accentuate the passivizing effects of this type of literature, because it locks women in traditional roles.

However, there have recently appeared alternative analyses of popular culture as a potential source of or resource for the mobilization of social change; its diffuse character has been seen as opening up the space for subversion parallel with the discourse of decadence in mapping the effects of popular culture. The differences in the interpretation of popular culture ranged from those that see it as a social problem that needs to be dealt with to those that contrarily see it as a social asset in a plural society. The field of the study of popular culture includes consequently the question of whether social structure holds primacy over culture in the processes of social change or of whether culture may potentially be the space for the creation of new political identities and movements (Lewis, 1978: 12). It is therefore necessary to move away from onesided views of the relationship between culture and society and to start from the analysis of interdiscursivity and the sociohistorically contingent negotiations between ideological forces contained in performing discourse.

The effects of Zagorka's writing can it seems be far better understood along these lines, especially if we take the perspective of communication with readers into account. Namely, although the romances she wrote confirmed the patriarchal matrix on the ideational level, they were the first widespread literature actually read by a great number of women. In pursuing what Janice Radway termed in her analysis of reading the romance (1991) an ethnographic turn to the reader, we separate the novel as a market product and its textuality from the very act of reading. Contrary to some mentioned androcentric readings of harmful effects of romances and popular culture for women in general, we claim that the act of reading is more subversive 
than what is read, whereby the spread of the market can play an important liberating function. Zagorka started writing engaged historical novels, with the aim to squeeze out German popular fiction1 and educate the readership in Croatian. Feuilletones, novels published in series, are the offspring of daily press intended for massive consumption (Nemec, 2006: 143).2 An important contextual assumption of this type of novel publication is the changed readership structure, because of obligatory schooling and the rise of literacy, which brought wider reception horizon, market democratization, and the fast growth of all types of language communication (Nemec, 2006: 143). The intended consumers were women, still prevailingly out of the public sphere and the labour market at the time (Watt, 1972). This is why the diversification in the production and consumption of culture had a liberating potential for women. Popular culture produced by Zagorka it seems then helped destabilise the boundary between the private and the public sphere, because it offered to women the possibility of the experience of being modern (together with fashion, magazines, department stores, romance novels etc.), and thus went hand in hand with the general democratization regarding the freedom of movement and the spread of literacy, which brought certain advancements to the positions of women.

The results of the analysis of Zagorka's place in Croatian cultural history show that the case of Zagorka and her popular literature cannot be adequately grasped from the perspective of the binary distinctions (male/female, highbrow/lowbrow, fact/fiction, public/private) that helped organize the discourse of social theory on modernization processes. The malestream criticism of popular romances in the context of early 20th century modernization is thereby particularly revealing, and the analysis has shown that a different, female-oriented reading of modernization is needed as a complement.

\subsection{The cultural politics of exclusion - on the dynamics of (in)visibility and the discourse of modernization}

Similarly to the position of popular culture which has until recently held the position of low visibility in sociological research, the problem of writing women into the cultural history and of their writing 3 are also the problems of (in)visibility, although both are and have been extremely present phenomena in the social life. The status of popular culture and of women's writing in the official cultural history are the symptoms of invisibility, which is in critical analysis of discourse an important factor of the processes of social exclusion and thus power. We have shown that from the perspective of live communication with readers, Zagorka's popular romances can be read alternatively to the customary pejorative criticism as potentially subversive and mobilizing social action. The reading of romances can thus be seen as a stake in the processes of democratization and modernization.

As a woman in the profession traditionally granting access to men only, Marija Jurić Zagorka was frequently faced with heavy insults and even disgust. Having a woman in the newspaper was a shame, but Zagorka's texts and feuilletones sold newspapers, so Zagorka was kept hidden as a madwoman in the attic of Obzor, the newspaper of her first employment.4 The ideological interests behind this degradation are to maintain the boundary between male and female spheres, to mystify the imagined essence of good journalism and literature, and exclude the threats to the positions of superiority and power. The reception of Zagorka and her work from the official critical establishment is well-illustrated by the labels attached to her: of a person who attacks everything that is elegant and cultured in Croatian society, because she is a writer of trash for peasants (cf. Lasić, 1986); a hermaphroditic type of woman who is out of her prescribed roles (in the kitchen, with children and in the church); the writer of pulp fiction courting the most vulgar taste (cf. Nemec, 2004: 651); literary weed and rubbish (cf. Kolanović, 2006: 327) etc. The mention of her is accordingly absent from the overviews of the history of Croatian literature and journalism; she is not even mentioned in the Obzor's Tribute Book published in 1936 although she was the editor in chief for a while. The Encyclopedia of the Yugoslav Institute of Lexicography gives only a circular entry on her: volume 4 (Zagreb, 1959: 55) directs from "Jurić, Marija" to "Zagorka"; and volume 7 (Zagreb, 1964: 737) directs from "Zagorka" to "Jurić, Marija".

On the contrary, Zagorka was visible and adored; her jubillaeums were celebrated, she received many letters from her readers, people waited in queues for her novels. She organized typographic workers into a union (Kolo radnih žena), conducted the first women's demonstrations in Croatia (especially during the regime of Khuen Héderváry), held hundreds of public lectures on women and politics, stepped out of traditional roles of women (which was interpreted as a sure sign of

\footnotetext{
1 The publication of German novels decreased by at least 70\% (Zagorka, 1953: 74).

2 The first such novel was Robinson Crusoe by Daniel Defoe, which unlike Zagorka's novels is free of similar pejorative criticism and is a classic.

3 We are aware of Foucault's recommendation that one should pursue a different ethos of academic reading, read and do research on everything (1996: 14), avoid the "possession" of the material, and forget about the author, but this is not the topic here.

${ }^{4}$ See Gubar and Gilbert (2000).
} 
insanity), proclaimed the necessity to reveal the role of women in history by publishing a series of women's portraits, discussed on the position of modern women, emancipation and gender equality, created pictures of active women etc. (Sklevicky, 1996). She was the editor-in-chief of the first Croatian magazines for women (Ženski list, 1925 to 1938, and Hrvatica, 1939 to 1940). She produced the largest opus in Croatian literature and was the most widely read Croatian writer 1 probably throughout the twentieth century (Nemec, 2004: 651). Zagorka dedicated her life to making women visible in public and created the possibility to articulate female experience, especially the experience of modernity. This is a contextual reason for reading her popular romances as possibly empowering, and not in line with the pejorative effects discussed above.

Critical denigration of Zagorka on the one hand and wide popularity on the other reveal the oppressiveness of critical labels given to Zagorka and her work and expose the discursive aspect of the ideological matrix with a gendered subtext. It is therefore methodologically and epistemologically important to reveal this part of female cultural production, together with the politics of concealment that has haunted it. It turns out that Zagorka was never actually absent, but only made invisible in the circles symbolically designated as belonging to high culture. She can therefore be called a public secret according to Tatjana Jukić (2012: 355, highlights in the original), because she is, as public, the knowledge of the community, not an individual, and thus political knowledge par excellence. As a secret, however, she is the knowledge that the community wishes to keep away from its legitimizing processes, but precisely because of that the knowledge that discloses the very conditions of the legitimizing processes in the community, and is thus political knowledge par excellence.

This dynamics of visibility, presence, and adoration of Zagorka on the one hand, and her invisibility, absence, and detestation on the other are mapped by the gender discourse, which is underwritten by the division of male and female spheres, the private and the public, work and home, culture and nature. The analysis of Zagorka's case reveals gender discourse as the one that maps the distinctions according to which we analyse for instance the differences in tastes (Bourdieu, 1984) or modes of cultural production and reception. Gender discourse is thus the confluence of scientific and literary writing, especially regarding the way in which the discourse of modernization has established itself, primarily by fundamentally relying on the exclusion of woman.

Woman is dominantly constructed through the discourse of non-alienated nature (and past), which is longed for, or the nature that needs to be put under control and civilised. Within the boundaries of the regime of power, as we shall see, Zagorka uses various strategies to try and mobilise feminist action, find a female political subject, and all that not by claiming any essence or nature of some imagined woman, but by occupying typically male domains and discourses - which is a strategically essentialist effort (Spivak, 1988) aware of the inability to find an authentic female voice, but not giving up political action on that account. Zagorka's position, the critiques that characterize her reception, the narrative techniques she used, and the conditions of distribution and publication of her work (serial publication) are treated here as contextual elements of discourse.

To autoreflect, this sociological investigation must not forget its own discursive presuppositions. Tönnies, Weber, and Simmel (Lichtblau, 1989) in their narratives on the modernization process for instance treat woman as the natural Other of culture (Sydie, 1987). The critique of classical sociological tradition warns against exclusive positioning of the modernizing process into the public sphere of work, bureaucracy, and market (Wolff, 1990), because such approach directly results in implicit or explicit exclusion of woman from it, putting her outside of the basic dynamics of social change (Sydie, 1987).

Riggs (1988), Radway (1986) and Bersani (1976) have accentuated that the critics of popular culture reduced female cultural practices by equating the consumption of lowbrow fiction with "swallowing" as a mechanistic and vulgar, and thereby perpetuated the ideology of aesthetic distinction which has a clear gender subtext. Consequently, consumerist society gets to be symbolically equated with the female principle: consumption is seductive, it gives pleasures and passivizes the consumer by capturing it within its reproductive strategies (Felski, 1995). The derogatory institutional critiques addressed to Zagorka as the writer of pulp have been analysed in this context. Still, the implications of the connections between women and consumption are not that simple. The dominant conceptualizations of the modernization process in social theory is

\footnotetext{
${ }^{1}$ A simple ethnography of reading done during a walk through the library reveals Zagorka's novels as very popular and read; contrary to for example canonical Krleža, whose books are mostly neat and tidy. To illustrate Zagorka' s popularity: her Grička vještica was published in 1963 in ten thousand copies, and then in 1964 in another ten. Collected works follow in 1972 in another ten to fifteen thousand (Hergešić, 1983: 398-401). In the preface to her works fifteen years after her death, Hergešić states that Zagorka is still in fashion (1983: 399), and Nemec in the afterword written about fifty years after her death (2004: 651) that Zagorka is becoming more visible in the discourse of academic disciplines. Her popularity persists: Zagorka's novels are being republished in both luxury (Školska knjiga) and paperack (EPH) editions, both with major interest of the reading audience.
} 
founded on the aspect of production, not consumption. However, to look at modernization also from the point of view of consumption would unmask the narrative of rationalization as a less convincing narrative of modernization, because consumption is not only a reflection of the economic interest; it is at the same time a desire reflecting gender and ideological interests. Not only goods, but also the very act of consumption are sold - which is trace Radway (1991) follows in her analytical separation of the novel as merchandise from the act of reading. Even if the dominant influence of the profit logic dominantly lurks from the background, the fact remains that romances, similar to fashion or department stores, influenced the sublimation of desire and the changes in the relationships of intimacy, as well as the changes in the patriarchal family, social and sexual identities.

To conclude, although woman may have been excluded (or sometimes despised) as a part of the natural pole that needs to be civilised and put under control at the early stage of modernization, she can become excluded also as a part of culture which is full of artificial glow and spectacle. This analysis thus does not aim to glorify the perspective of the consumer as subversive in itself, but only serves to challenge the distinctions that produced an over-simplified picture of female cultural practices and the female experience of and role in the modernization process. Although the act of reading romances could have had a relatively empowering effect for women, it simultaneously meant the appearance of new forms of control and discipline (especially over gender).

The less visible control means the more effective discipline. The question of the final outcome of the hegemonic struggle therefore remains. To conclude in an autoreflective tone, Zagorka is today more visible both in academic circles 1 and outside of them, 2 warning us that there is a cultural politics to it, because new visibilities produce some other invisibilities against which they establish themselves.

\section{Conclusion}

This paper offered an attempt to deconstruct the discursive construction of some myths that conceal the cultural politics helping shape our social and cultural imaginary. We applied the qualitative method of critical discourse analysis to look into the processes that produced the dual position of Marija Jurić Zagorka and her writing, aimed primarily at providing the ideology critique. To avoid the dangers of discursive determinism and the consequent view of social actors as impotent and passive, the aspect of discourse as social practice was particularly stressed and the theory of hegemony was offered, as the one better suited than the dominant ideology approaches, for the analysis of the struggle between different voices for a certain positioning in the order of discourse (Zagorka's feminist political goals in the patriarchal matrix). The heritage of Foucault's method was discussed with the perspective of introducing a theory of action and of discovering possible subversive strategies at disposal to social actors.

The discursive approach interested in analysing power helped reveal the coupling of popular culture and women, here through the analysis of contextualized meanings and negotiations with a certain audience and through ideological interdiscursive forces that constitute dominant meanings. The exclusion of Zagorka from serious literary discussions and overviews of the history of Croatian culture and literature is shown to be an effect of gendered distinctions that organize the social space. The position of Marija Jurić Zagorka as a woman and the writer of popular fiction in the Croatian cultural history is exposed to be relevantly determined by the distinctions that also help establish a certain view of the processes of (cultural) modernization and that strategically work to preserve the dominant status of man as producer of culture.

Zagorka was viewed pejoratively primarily on two accounts: for following the simplified narrative framework in her romances that keep spoiling the readership and 'doing harm' to young women, and for pursuing the logic of market and profit in the discursive practice of her writings (serially published novels, which are enormously long). The results of our critical analysis of gender discourse reveal the ideological burden of such criticism and its patriarchal and androcentric subtext. The analysis deals with a very specific and concrete example to show that rather than distinction-and-quality-reducing (dangerous) and stupefying, Zagorka's novels are, from the perspective of live communication with her audience, actually empowering for women, because the act of reading is seen as more important than what was read (cf. the ethnographic turn to the reader, Radway, 1991). Zagorka's popular romances thus provided the experience of modernity for that half of the population which

\footnotetext{
${ }^{1}$ This very paper is a contribution to that visibility. Also, there is an international scientific conference dedicated to Zagorka going on since 2007, with the fifth proceedings published.

2 There is a film Zagorka directed by Biljana Čakić Veselič (FADE IN, HRT, Zagreb film, 2008); a play Zagorka by Ivica Boban; a millennium photograph was taken in 2012 by photographer Šime Strikoman of the people named after Zagorka's characters; the press room in the Croatian parliament is named "Marija Jurić Zagorka"; an annual award for written journalism is called after her...
} 
was still predominantly locked in the private sphere in the first half of the 20th century. In this sense, this analysis is the contribution to the critiques of the theories of modernization in social theory, bringing the perspective that takes account of the female experience, the private sphere, and the logic of consumption (and not only of the public sphere of work, politics, rationalization) in the formation of what we call modernity. Although Zagorka leans against a dominant discourse and follows the market logic, the results show a possible (subversive) intervention into the sphere of discursive practices (hegemonic struggle of different voices for supremacy in the order of discourse defining the reception of Zagorka) and indicate that detailed empirical research on discursive effects in a series of domains is a method of research on political investment of the order of discourse into social change. The problems of the final outcome of the hegemonic struggle, new forms of discipline silently introduced by Zagorka's new visibility, and a possibly different interpretation remain.

\section{References}

Abercrombie, N., Hill, S., \& Turner , B. S. (2008). Rječnik sociologije. Zagreb: Naklada Jesenski i Turk.

Althusser, L. (1971). Ideology and ideological state apparatuses. In L. Althusser (Ed.), Lenin and Philosophy and Other Essays (pp. 127-186). New York: Monthly Review Press.

Bannister, P. (1995). Qualitative methods in psychology a research guide. Buckingham: Open University Press.

Beaugrande, R. de. (1996). Psycholinguistics and sociolinguistics: Looking back and ahead. In V. Patras (Ed.), Sociolingvisticke a Psycholingvisticke Aspekty (pp. 15-26). Bystríca: Univerzita Mateja Bela Fakulta Jazykovej Komunikacie.

Beaugrande, R. de. (2006). Critical Discourse Analysis: History, ideology, methodology. Studies in Language \& Capitalism 1, 29-56.

Bersani, L. (1976). A Future for Astyanax: Character and Desire in Literature. Boston: Little, Brown, \& Co.

Blommaert, J. \& Bulcaen, C. (2000). Critical Discourse Analysis. Annual Review of Anthropology, 29, 447-66.

Bourdieu, P. (1984). Distinction: A Social Critique of the Judgement of Taste. Cambridge: Harvard University Press.

Burke, P. (1978). Popular Culture in Early Modern Europe. London: Temple Smith.

Cameron, D. (2001). Working with spoken discourse. Thousand Oaks, CA: Sage.

Chalaby, J. K. (1996). Beyond the prison-house of language: Discourse as a sociological concept. British Journal of Sociology, 47 (4), 684-698.

Dreyfus, H. \& Rabinow, P. (1982). Michel Foucault: beyond structuralism and hermeneutics. Brighton: Harvester Press.

Fairclough, N. (1992). Discourse and Social Change. Cambridge: Polity Press.

Fairclough, N. (1995). Critical discourse analysis: the critical study of language. London and New York: Longman.

Fairclough, N. (2001). Critical discourse analysis as a method in social scientific research. In R. Wodak \& M. Meyer (Ed.), Methods of Critical Discourse Analysis (pp. 121-138). London: Thousand Oaks.

Felski, R. (1995). The Gender of Modenrity. Cambridge, Massachusetts, London: Harvard University Press.

Foucault, M. (1981). History of sexuality, Vol. I. Harmondsworth: Penguin Books.

Foucault, M. (1982). The subject and power. In H. Dreyfus \& P. Rabinow (Ed.), Michel Foucault: beyond structuralism and hermeneutics (pp. 208-226). Chicago: University of Chicago Press.

Foucault, M. (1989). Archaeology of Knowledge. London and New York: Routledge Classics.

Foucault, M. (1996). Foucault live: Collected interviews, 1961-1984. New York: Semiotext(e).

Gilbert, S. M. \& Gubar, S. (2000). The Madwoman in the Attic. The Woman Writer and the Nineteenth-Century Literary Imagination. New Haven, London: Yale University Press.

Gramsci A. (1971). Selections from Prison Notebooks. London: Lawrence and Wishart.

Grant, D., Keenoy, T. \& Oswick, C. (1998). Organizational discourse: Of diversity, dichotomy and multi-disciplinarity. In D. Grant, T. Keenoy, and C. Oswick (Ed.), Discourse and organization (pp. 1-14). London: Sage.

Hergešić, I. (1983). Predgovor Sabranim djelima (1972). In R. Bogišić (Ed.), Pet stoljeća hrvatske književnosti, book 122: Josip Horvat, Josip Torbarina, Ivo Hergešić (pp. 376-402). Zagreb, Nakladni zavod Matice Hrvatske.

Hook, D. (2001). Discourse, knowledge, materiality, history: Foucault and discourse analysis [online]. London: LSE Research Online. Available at: http://eprints.Ise.ac.uk/archive/956

Jukić, T. (2012). Republikanci i revolucija: politika Zagorkine književnosti. In T. Bogdan et al. (Ed.), Perivoj od slave. Zbornik Dunje Fališevac (pp. 355-364). Zagreb: FF press.

Jurić Zagorka, M. (1953). Kako je bilo. Beograd: Izdanje redakcije Zabavnog romana. Jurić, Marija. (1959). Enciklopedija Leksikografskog zavoda SFRJ. Volume 4. Zagreb.

Kendall, G. \& Wickham, G. (1999). Using Foucault's Methods. London: Sage. 
Kolanović, M. (2006). Od pripovjedne imaginacije do roda i nacije: Marija Jurić Zagorka u kontekstu žanra romanse. In V. Brešić (Ed.), Osmišljavanja. Zbornik u čast 80. rođendana akademika Miroslava Šicela (pp. 327-358). Zagreb: FF press. Lasić, S. (1986). Književni počeci Marije Jurić Zagorke. Uvod u monografiju. Zagreb: Znanje.

Lewis, G. H. (1978). Trend Report: The Sociology of Popular Culture. Current sociology, 26 (3), 3-64.

Lichtblau, K. (1989). Eros and Culture: Gender Theory in Simmel, Tönnies, and Weber. Telos, 82, 89-110.

Litosseliti, L. \& Sunderland, J. (2002). Gender Identity and Discourse Analysis: Theoretical and Empirical Considerations. In J. Sunderland \&and L. Litosseliti (Ed.), Gender Identity and Discourse Analysis (pp. 1-39). Amsterdam: Benjamins.

McHoul, A. \& Grace, W. (1997). The Foucault primer. New York: New York University Press.

Meyer, M. (2001). Between theory, method, and politics: positioning of the approahes to CDA. In R. Wodak \& M. Meyer (Ed.), Methods of Critical Discourse Analysis (pp. 14-31). London, Thousand Oaks, New Delhi: Sage.

Modleski, T. (2008). Loving with a Vengeance: Mass produced fantasies for women. (2nd edition). New York and London: Routledge.

Nemec, K. (2004). Stroj za proizvodnju priča. In M. Jurić Zagorka, Grička vještica 7, Collected Workd of Marija Jurić Zagorka, vol. 7 (pp. 651-663). Afterword. Zagreb: Školska knjiga and Naklada Marija Jurić Zagorka, str. 651-663.

Nemec, K. (2006). Od feljtonskih romana i "sveščića" do sapunica i Big Brothera, In K. Bagić (Ed.), Raslojavanje jezika i književnosti: zbornik radova 34. seminara Zagrebačke slavističke škole (pp. 143-158). Zagreb: Filozofski fakultet, Zagrebačka slavistička škola, Hrvatski seminar za strane slaviste.

Parker, I. (1992). Discourse dynamics: critical analysis for social and individual psychology. London: Routledge.

Phillips, N. \& Hardy, C. (2002). Discourse Analysis: Investigating Processes of Social Construction. Sage University Papers Scenes on Qualitative Research Methods, Vol 50. Thousand Oaks, CA: Sage.

Potter, J. \& Wetherell, M. (1987). Discourse and social psychology: beyond attitudes and behaviour. London: Sage.

Radway, J. (1986). Reading Is Not Eating: Mass-Produced Literature and the Theoretical, Methodological, and Political Consequences of a Metaphor. Book Research Quarterly, 2 (3), 10-11.

Radway, J. (1991). Reading the Romance: Women, Patriarchy and Popular Literature. Chapel Hill, London: The University of North Carolina Press.

Riggs, L. (1988). Bovarysme Reconsidered: Self-Promotion, Commercialized Print, and the Birth of a Consumer Culture.

In R. L. Hadlich \& J. D. Ellsworth (Ed.), East Meets West: Homage to Edgar C. Knowlton, Jr. (pp. 235-246). Honolulu: University of Hawaii, Department of European Languages and Literature.

Rose, N. \& Miller, P. (1992). Political Power beyond the State: Problematics of Government. The British Journal of Sociology, 43 (2), 173-205.

Sklevicky, L. (1996). Konji, žene, ratovi. Zagreb: Druga.

Snitow, A. B. (1996). Mass Market Romance: Pornography for Women is Different. In M. Eagleton (Ed.), Feminist Literary Teory. A Reader. Oxford-London: Blackwell.

Spivak, G. C. (1988). Can the Subaltern Speak? In C. Nelson \& L. Grossberg (Ed.), Marxism and the Interpretation of Culture (pp. 271-313). Urbana: University of Illinois Press.

Strinati, D. (2004). Introduction to Theories of Popular Culture. London: Routledge.

Sydie, R. A. (1987). Natural Women, Cultured Men: A Feminist Perspective on Sociological Theory. Milton Keynes: Open University Press.

van Dijk, T. A. (1990). Discourse \& Society: a new journal for a new research focus. Discourse \& Society, 1, 5-16.

van Dijk, T. A. (1997). Discourse as interaction in society. In T. A. van Dijk (Ed.), Discourse as social interaction (pp. 1-37). London: Sage.

Watt, I. (1972). The Rise of the Novel: Studies in Defoe, Richardson and Fielding. Harmondsworth: Penguin.

Wetherell, M. (2001). Debates in discourse research. In M. Wetherell, S. Taylor, \& S. J. Yates (Eds.), Discourse theory and practice: A reader (pp. 380-399). London: Sage.

Williams, R. (1976). Keywords: A Vocabulary of Culture and Society. London, Fontana.

Williams, R. (1981). Culture. London: Fontana.

Wodak, R. \& Meyer, M. (2001). (Eds.) Methods of Critical Discourse Analysis. London, Thousand Oaks, New Delhi: Sage. Wolff, J. (1990). Feminine Sentences: Essays on Women and Culture. Oxford: Polity press.

Woodilla. J. (1998). Workplace conversations: The text of organizing. In D. Grant, T. Keenoy \& C. Oswick (Eds.), Discourse and organization (pp. 31-50). London: Sage.

Young, R. (1981). (Ed.). Untying the text: a post-structural anthology. Boston: Routledge \& Kegan Paul.

Zagorka. 1964. Enciklopedija Leksikografskog zavoda SFRJ. Svezak 7. Zagreb. 
